\title{
ANALISIS ANTESEDEN PADA SIKAP DAN NIAT MENGGUNAKAN BLACKBERRY DENGAN DASAR MODEL PENERIMAAN TEKNOLOGI
}

\author{
Istyakara Muslichah \\ Faculty of Economics, Universitas Islam Indonesia, Yogyakarta \\ e-mail: istyakara@gmail.com
}

\begin{abstract}
The competition in smartphone industry forces marketers and marketing researchers to understand the consumers' motif in term of their intention to use smrtphone. This study then proposed to examine the antecedent of attitute towards using and intention to use BlackBerry which are entertainment, social interaction, permanent access, pass time, and status/fashion. Those factors are extended from Technology Acceptance Model (TAM). This study was conducted using quantitative approach with survey method and data was collected using questionnaire. There was 160 questionnaires collected from college studentsin Yogyakarrta. Using multiple regression analysis, the findings show that entertainment, social interaction, permanent access, and pass time positively affects the attitude towards using BlackBerry. While status/fashion does not affect the attitude towards using BlackBerry. The attitude towards using BlackBerry also positively affects the intention to use BlackBerry.
\end{abstract}

Keywords: BlackBerry, TAM, attitude towards using, intention to use

\begin{abstract}
Abstrak
Kompetisi pada industri smartphone mendorong para peneliti dan praktisi utuk mengetahui motif konsumen di balik intensi mereka untuk menggunakan smartphone. Penelitian ini bertujuan untuk menganalisis anteseden pada sikap terhadap penggunaan dan niat menggunakan BlackBerry diYogyakarta. Anteseden pada sikap terhadap penggunaan tersebut terdiri dari lima faktor, yaitu hiburan, interaksi sosial, akses permanen, pelengah waktu, dan status/mode. Lima faktor tersebut merupakan perpanjangan dari model penerimaan teknologi (Technology Acceptance Model). Penelitian ini menggunakan pendekatan kuantitatif dengan metode survei menggunakan kuesioner. Terkumpul 160 kuesioner dari responden yang merupakanmahasiswa perguruan tinggi di Yogyakarta.Dengan menggunakan analisis regresi berganda, diperoleh hasil bahwa sikap terhadap penggunaan BlackBerry terbukti dipengaruhi oleh hiburan, interaksi sosial, akses permanen, dan pelengah waktu. Sedangkan variabel status/mode tidak berpengaruh pada sikap terhadap penggunaan BlackBerry. Selanjutnya, dilakukan analisis regresi sederhana dan diperoleh hasil bahwa sikap terhadap pengggunaan BlackBerry berpengaruh positif pada niat menggunakan BlackBerry.
\end{abstract}

Kata kunci: BlackBerry, TAM, sikap terhadap penggunaan, niat menggunakan

\section{PENDAHULUAN}

Smartphone (telepon pintar) merupakan salah satu temuan dalam teknologi komunikasi yang banyak digunakan oleh masyarakat hing saat ini. Puro (2002) menyatakan bahwa di Eropa dan Asia, telepon seluler dianggap jauh lebih umum dari pada di AS. Orang-orang muda telah menjadi kekuatan pendorong yang lainnya dalam mengadopsi perangkat komunikasi baru. Finlandia, di mana tingkat penetrasi telepon seluler tertinggi di dunia, lebih dari $90 \%$ dari orang di bawah 30 tahun telah memiliki sebuah perangkat sendiri. Hal ini juga didukung oleh hasil riset Wireless Intelligent tahun 2008 yang menyebutkan bahwa Indonesia masuk dalam 6 besar daftar negara dengan jumlah pelanggan seluler sebanyak 116 juta. Pengguna internet di Indonesia juga menunjukkan angka yang tinggi, yaitu 88,1 juta jiwa berdasarkan (APJII dan Puskakom, 2015). 
Data dan informasi tersebut, membuat para pemasar industri ini harus pintar menganalisis perilaku konsumen untuk meningkatkan performa dalam aktivitas pemasarannya. Asumsi yang mendasari konsep pemasaran adalah suatu perusahaan harus menentukan kebutuhan dan keinginan berbagai target pasar tertentu dan memberikan kepuasan yang diinginkan lebih baik daripada pesaing (Kotler dan Amstrong, 2008, h. 10). BlackBerry sebagai salah satu pemain di dunia smartphone mencoba menarik konsumen dengan menampilkan fitur-fitur andalan yang berbeda dari produk lainnya. Hal ini kemudian mendapat respon positif di pasar Indonesia. Pasar produk keluaran RIM tersebut berhasil naik 8,6\% menggeser pasar Nokia yang menjadi turun 10\% (Mix, 2009).

Perspektif kegunaan dan kepuasan fokus menjelaskan motif sosial dan psikologis yang mempengaruhi orang untuk memilih media tertentu untuk memuaskan satu set kebutuhan psikologis (Katz dan Blumler, 1974). Rubin (1984) kemudian mengatakan bahwa konsumen mencoba memenuhi kebutuhan psikologis dalam media pilihannya. Mencari kepuasan memotivasi mereka untuk menggunakan suatu media sehingga pilihan tersebut datang dari kepercayaan atau ekspektasi bahwa media terpilih dapat memuaskan kebutuhan spesifik mereka. Ruggiero (2000) juga menyatakan bahwa kegunaan dan kepuasan selalu memberikan pendekatan teoritis terdepan dalam tahap awal masing-masing media komunikasi massal baru seperti surat kabar, radio, televisi, dan internet. Fishbein dan Ajzen (1975) mengatakan sikap seseorang terhadap objek tergantung pada kepercayaan seseorang yang sudah dibandingkan dengan evaluasi pada kepercayaan lainnya sehingga ekspektasi seseorang mengenai kegunaan dan kepuasan pada suatu media akan berpengaruh positif pada sikap mereka terhadap penggunaan media. Dengan demikian, dapat dikatakan bahwa faktor pendorong berkaitan dengan harapan seseorang mengenai kepuasan dan kegunaan akan suatu media berpengaruh pada sikap mereka terhadap media tersebut.

Penelitian ini menganalisis faktorfaktor anteseden yang mempengaruhi seseorang pada sikap dan niat menggunakan BlackBerry. Dengan menggunakan dasar Model Penerimaan Teknologi oleh Davis
(1989), didapat pengembangan faktor-faktor anteseden seperti hiburan, interaksi sosial, akses permanen, pelengah waktu, dan status/mode (Choi et al., 2009). Faktor-faktor tersebut dianalisis pengaruhnya pada sikap terhadap penggunaan BlackBerry. Selanjutnya, sikap terhadap penggunaan BlackBerry dianalisis pengaruhnya pada niat menggunakan BlackBerry. Hasil penelitian ini nantinya diharapkan dapat bermanfaat bagi para pemasar smartphone pada umumnya dan BlackBerry pada khususnya di Indonesia agar dalam mengembangkan produknya dapat sesuai dengan apa yang diinginkan konsumen.

\section{KAJIAN PUSTAKA}

\section{Model Penerimaan Teknologi [Technology Acceptance Model (TAM)]}

Beberapa model yang dibangun untuk menganalisis dan memahami faktor-faktor yang mempengaruhi diterimanya penggunaan teknologi, di antaranya yang tercatat dalam berbagai literatur dan referensi hasil riset dibidang teknologi informasi adalah Theory of Reasoned Action (TRA), Theory of Planned Behaviour (TPB) dan Technology Acceptance Model (TAM) (Vijayasarathy, 2003).TRA merupakan gagasan dari Fishbein dan Ajzen (1975) yang kemudian dikembangkan menjadi TPB oleh Ajzen (1991) dan TAM oleh Davis (1989). TAMadalah model yang dikembangkan dengan dasar TRA yang (1) menentukan bagaimana mengukur komponen perilaku relevan dari sikap, (2) membedakan antara keyakinan dan sikap serta (3) menentukan bagaimana stimulus eksternal, seperti fitur objektif dari objek sikap secara kausal terhubung dengan keyakinan, sikap, dan perilaku (Fishbein dan Ajzen, 1975). Mereka menggambarkan perbedaan antara dua konstruk sikap: sikap terhadap objek (attitude toward the object/Ao) yang merujuk pada evaluasi afektif seseorang dalam objek sikap tertentu, dan sikap terhadap perilaku (attitude toward the behavior/Ab) yang merujuk pada evaluasi seseorang pada perilaku tertentu yang melibatkan objek.

Berdasakan Fishbein dan Ajzen (1975), sikap konsumen terhadap produk atau merek spesifik merupakan fungsi kehadiran dan evaluasi dari produk spesifik tertentu. Berbeda dengan sikap terhadap perilaku, hal ini merupakan sikap untuk berperilaku atau 
bertindak sehubungan dengan objek, bukan sikap terhadap obyek itu sendiri. Model sikap terhadap perilaku mengusulkan bahwa sikap seorang konsumen terhadap suatu perilaku tertentu merupakan fungsi dari seberapa kuat ia percaya bahwa tindakan ini akan mengakibatkan hasil tertentu, baik menguntungkan atau tidak menguntungkan. Hal itu menunjukkan bahwa $\mathrm{Ab}$ berhubungan lebih kuat pada perilaku tertentu dari pada Ao (Fishbein dan Ajzen, 1975). Oleh karena itu, dalam mengusulkan TAM, sikap terhadap perilaku (penggunaan sistem) akan dibahas lebih lanjut.

Berdasarkan TRA, keputusan yang dilakukan oleh individu untuk menerima suatu teknologi merupakan tindakan sadar yang dapat dijelaskan dan diprediksi oleh niat perilakunya (Davis, 1989). Hal ini diaplikasikan dalam memperluas teori TRA pada model penerimaan teknologi (TAM) yang dapat digunakan untuk menjelaskan adopsi teknologi informasi dalam berbagai konteks.Model ini mampu mengatasi keterbatasan TRA yang sebenarnya dalam meprediksi perilaku secara akurat hanya bias pada kondisi tertentu yang spesifik (Dharmmesta, 1992). Secara keseluruhan TAM terdiri dari lima konsep: kegunaan yang dipersepsikan, kemudahan penggunaan yang dipersepsikan, sikap terhadap penggunaan, niat menggunakan, dan penggunaan sesungguhnya (Davis, 1989).

Menurut Davis (1989), kegunaan yang dipersepsikan didefinisikan sebagai tingkat dimana individu percaya bahwa menggunakan sistem tertentu dapat meningkatkan performa kerjanya. Seseorang akan menggunakan suatu teknologi apabila ia percaya bahwa teknologi tersebut berdaya guna. Sebaliknya, seseorang tidak akan menggunakan suatu teknologi apabila ia percaya bahwa teknologi tersebut kurang berguna. Nysveen et al. (2005a, b) dalam penelitianya pada layanan mobile menunjukkan bahwa konsep kegunaan yang dipersepsikan berpengaruh positif pada sikap terhadap penggunaan suatu teknologi.Schierz (2010) dan Akturan, dan Tezcan (2012)juga membuktikan bahwa kegunaan yang dipersepsikan berpengaruh pada penerimaan konsumen terhadap teknologi pembayaran mobile.

Konsep kedua dalam TAM adalah kemudahan penggunaan yang dipersepsikan. Konsep ini didefinisikan sebagai tingkat dimana individu percaya bahwa menggunakan sistem tertentu akan membebaskan dari usaha fisik dan mental (Davis, 1989). Sama halnya dengan kegunaan yang dipersepsikan, seseorang akan berniat untuk menggunakan suatu teknologi apabila ia percaya bahwa teknologi tersebut mudah digunakan. Begitu juga sebaliknya. Penelitian pada layanan mobile (Nysveen et al., 2005b) juga menunjukkan bahwa kemudahan penggunaan yang dipersepsikan memiliki pengaruh langsung dan tidak langsung (melalui kegunaan yang dipersepsikan) pada sikap terhadap penggunaan. Selain itu, kemudahan yang dipersepsikan juga berpengaruh pada niat menggunakan layanan mobile (Hung et al., 2003) dani-banking (Nasri \& Charfeddine, 2012).

Konsep ketiga dalam TAM adalah sikap terhadap perilaku. Azjen dan Fishbein (1975) mendefinisikan sikap terhadap penggunaan sebagai perasaan negatif atau positif seseorang (perasaan evaluatif) mengenai melakukan perilaku sasaran. Dalam penelitian layanan mobile oleh Nysveen et al. (2005b), hasilnya menunjukkan bahwa sikap terhadap perilaku memiliki efek langsung pada niat menggunakan. Hasil tersebut juga didukung oleh oleh Choi et al. (2009) yang meneliti niat menggunakan TV mobile di Korea Selatan, menunjukkan bahwa sikap terhadap penggunaan berpengaruh pada niat menggunakan TV mobile.

Konsep keempat dalam TAM adalah niat menggunakan. Berdasarkan Fishbein dan Ajzen (1975), niat menggunakan merupakan kekuatan dari niat seseorang untuk melakukan perilaku tertentu. Suatu perilaku akan dilakukan oleh seseorang apabila terlebih dahulu dia telah memiliki sebuah niat. Semakin besar niat seseorang untuk melakukan suatu perilaku, semakin besar kemungkinan perilaku tersebut menjadi nyata. Niat menggunakan merupakan prediksi yang baik kepada konsep terakhir dalam TAM, yaitu perilaku. Berdasarkan TAM, penelitian-penelitian terdahulu menunjukkan bahwa sikap berpengaruh pada niat berperilaku, dan niat berperilaku berpengaruh pada perilaku sesungguhnya (Nysveen et al., 2005b).

\section{Studi Terdahulu dengan Mengembangkan Model Penerimaan Teknologi}

Pada awalnya, TAM diajukan untuk studi yang terkait dengan sistem/teknologi informasi 
(Davis, 1993; Venkatesh, 2003), khususnya teknologi komputer (Davis et al, 1989). Namun, beberapa studi kemudian mencoba menerapkan TAM untuk meneliti penerimaan penggunaan teknologi baru untuk email, voice mail, pengolah kata, spreadsheet, program basis data, editor berkas, sistem grafis, sistem pendukung keputusan, World-Wide Web dan beberapa lainnya. Pada dasarnya, hasil studistudi tersebut mendukung model tersebut (Wang et al., 2005).

Studi penerimaan teknologi di luar sistem informasi banyak yang melakukan eksplorasi terkait dengan variabel-variabel pembentuknya. Wang et al. (2005) telah meneliti penerimaan teknologi Instant Messaging Servicse (IMS). Wang menambahkan dua variabel pembentuk variabel kegunaan yang dipersepsikan. Variabel tambahan tersebut adalah utilitas teknologi (technology utility) dan jumlah pengguna (number of users). Hasil penelitian tersebut menunjukkan bahwa kedua variabel tersebut berpengaruh pada kegunaan yang dipersepsikan.

Teo et al. (1999) dalam penelitiannya pada niat menggunakan internet menjabarkan variabel-variabel pembentuk penggunaan internet. Terdapat tiga variable, yaitu kegunaan yang dipersepsikan, kesenangan yang dipersepsikan, dan kemudahan penggunaan yang dipersepsikan. Hasil penelitiannya menunjukkan bahwa kegunaan yang dipersepsikan dan kesenangan yang dipersepsikan berpengaruh langsung pada penggunaan internet. Sedangkan kemudahan penggunaan yang dipersepsikan berpengaruh secara langsung dan tidak langsung (melalui variabel kegunaan yang dipersepsikan dan kesenangan yang dipersepsikan) pada penggunaan internet (Teo et al, 1999).

Nysveen et al. (2005a,b) dalam penelitiannya di bidang layanan mobile menyarankan empat faktor pendukung dalam niat konsumen untuk menggunakan layanan mobile, yaitu kegunaan, kemudahan penggunaan, kesenangan, dan keekspresifan yang dipersepsikan. Faktorfaktor pendorong tersebut kemudian juga dibedakan menjadi dua bentuk, yaitu ekstrinsik dan intrinsik. Faktor pendorong ekstrinsik (kegunaan yang dipersepsikan, kemudahan penggunaan yang dipersepsikan,) merujuk pada pencapaian atas target tertentu atau imbalan, sedangkan faktor pendorong intrinsik (kesenangan yang dipersepsikan, keekspresifan yang dipersepsikan) merujuk pada kesenangan dalam melakukan suatu kegiatan

Choi et al. (2009) meneliti motivasi konsumen pada niat menggunakan TV mobile di Korea Selatan. Hasil penelitiannya menyebutkan faktor pendorong seseorang dalam menggunakan TV mobile antara lain adalah hiburan, interaksi sosial, akses permanen, pelengah waktu, dan status/mode. Faktor-faktor tersebut sesuai dengan Leung dan Wei (2000) yang menyebutkan bahwa perhatian/pergaulan (yang dapat dibandingkan dengan interaksi sosial), akses langsung (yang dapat dibandingkan dengan akses permanen), mobilitas (yang dapat dibandingkan dengan pelengah waktu), dan perantara berpengaruh pada prediksi penggunaan telepon seluler. Choi et aljuga membuktikan bahwa sikap memediasi hubungan antara faktor-faktor tersebut dan niat menggunakan TV mobile. Nysveen et al. (2005b) juga menyatakan bahwa kesenangan (yang dapat dibandingkan dengan hiburan) dan keekspresikan (yang dapat dibandingkan dengan status/mode) berpengaruh positif pada sikap terhadap penggunaan dan niat menggunakan telepon seluler.

\section{Hiburan}

Hiburan adalah kegiatan yang dinikmati dan banyak orang berharap untuk melakukannya (Christiansen dan Brinkerhoff-Jacobs, 1995). Sumber-sumber hiburan terletak pada imajinasi, fantasi, dan dorongan manusia untuk menciptakan. Nysveen et al.(2005a) mendefinisikan kesenangan yang dipersepsikan (yang bisa dibandingkan dengan hiburan) adalah tingkat keyakinan suatu kegiatan menggunakan komputer (teknologi) dipersepsikan menjadi sesuatu yang secara pribadi menyenangkan di luar dari nilai instrumental teknologinya. O'Keefe dan Sulanowski (1995) juga membuktikan bahwa hiburan merupakan faktor pendorong seseorang untuk menggunakan telepon. Selain itu, kesenangan yang dirasakan dari menggunakan layanan mobile juga menjadi motivasi intrinsik yang penting bagi niat terhadap layanan mobile (Koufaris, 2002).

H1: Hiburan berpengaruh positif pada sikap terhadap penggunaan BlackBerry

\section{Interaksi Sosial}

Jin dan Villegas (2008) menyatakan bahwa bersoasialisasi antara lain dapat menghubungi 
orang lain dan berkomunikasi dengan kelompok sosial. Taylor dan Harper (2001) mengatakan bahwa orang-orang muda saling berkirim pesan sebagai bentuk hadiah yang memiliki arti khusus dalam kehidupan dengan maksud untuk mempererat hubungan sosial. Leung dan Wei (2000) menyebutkan faktor perhatian dan pergaulan (yang dapat dibandingkan dengan interaksi sosial) merupakan pendorong penggunaan telepon seluler sebagai wujud perhatian. Hasil penelitiannya menunjukkan bahwa berkomunikasi dengan asisten kerja dan rekan bisnis melalui telepon seluler ditunjukkan untuk alasan instrumental sedangkan bercakap-cakap dengan keluarga menunjukkan perhatian. Hasil penelitiannya mengatakan bahwa menjalin interaksi sosial dengan orang lain dilakukan dengan menggunakan media mobile.

Aoki dan Downes (2002) dalam penelitiannya menemukan setengah pemilik ponsel selalu membawa ponsel mereka. Hal tersebut menunjukkan bahwa berinteraksi dengan orang lain merupakan salah satu kegunaan penting dari sebuah telepon mobile. Jin dan Villegas (2008) juga menyatakan bahwa telepon mobile diterima sebagai alat komunikasi pribadi dan penggunanya senang untuk bersoasialisasi dengan menggunakannya, termasuk dapat menghubungi orang lain dan berkomunikasi dengan kelompok sosial. Taylor dan Harper (2001) juga mencatat bahwa orangorang muda menggunakan telepon, terutama fitur pesan, sebagai bentuk imbalan yang dipertukarkan dalam perbuatan dan memiliki arti khusus dalam kehidupan sehari-hari anakanak muda dan dilakukan dengan maksud untuk mempererat hubungan sosial.

$\mathrm{H} 2$ : Interaksi sosialberpengaruh positif pada sikap terhadap penggunaan BlackBerry

\section{Akses Permanen}

Leung dan Wei (2000) membuktikan bahwa akses langsung merupakan faktor pendorong seseorang untuk menggunakan telepon seluler. Akses permanen didefinisikan sebagai faktor yang mengakomodasi pengguna untuk mendapatkan akses langsung tanpa harus memikirkan waktu dan tempatnya, sejauh dan selama apapun. Halangan mobilitas dengan keluarga dapat diatasi dengan penggunaan telepon seluler.

Leung dan Wei (2000) juga membuktikan bahwa mobilitas dan akses langsung meru- pakan faktor kepuasan yang mendorong seseorang untuk menggunakan telepon seluler yang sebelumnya belum teridentifikasi pada literatur sebelumnya. Hal ini menunjukkan bahwa telepon seluler memungkinkan penggunanya untuk selalu mendapatkan akses langsung tanpa harus memikirkan waktu dan tempatnya, terutama dapat selalu ada bagi anggota keluarga yang lebih tua atau sedang sakit. Teknologi telepon nirkabel baru memaksimalkan kebebasan dalam mobilitas yang juga mendorong akses langsung hingga sejauh dan selama apapun. Sejalan dengan hal ini, Choi et al. (2009) juga membuktikan bahwa permanen akses secara umum berpengaruh positif pada sikap dan niat untuk menggunakan TV mobile.

H3: Akses permanen berpengaruh positif pada sikap terhadap penggunaan BlackBerry

\section{Pelengah Waktu}

Choi et al. (2009) mendefinisikan pelengah waktu sebagai fungsi yang membantu seseorang melengahkan waktu ketika mempersepsikan TV mobile. Walaupun hasil penelitiannya menunjukkan bahwa pelengah waktu tidak berpengaruh positif pada sikap terhadap penggunaan TV mobile, Leung dan Wei (2000) dalam penelitiannya menyimpulkan bahwa pelengah waktu terbukti sebagai faktor pendorong penggunaan telepon dan PDA. Papacharissi dan Rubin (2000) juga menemukan bahwa pelengah waktu muncul sebagai faktor pendorong penggunaan internet.

$\mathrm{H} 4$ : Pelengah waktuberpengaruh positif pada sikap terhadap penggunaan BlackBerry

\section{Status/mode}

Choi et al. (2009) mendefinisikan status/mode sebagai fungsi untuk dapat mengekspresikan dirinya sebagai pionir mode atau pencipta gaya (trendsetter). Leung dan Wei (2000) juga mengatakan bahwa memiliki dan menggunakan telepon mencerminkan gaya hidup konsumtif sehingga status dan mode tersebut menjadi faktor pendorong seseorang dalam pengadopsiannya. Leung dan Wei (2000) semakin menguatkan hal tersebut setelah menemukan bahwa status/mode menjadi faktor kuat pendorong seseorang dalam menggunakan media mobile. Campbell (2007) juga membandingkan persepsi terhadap ponsel pada lima lokasi: Hawai, Jepang, Swedia, Taiwan dan Amerika Serikat. Hasilnya, terdapat persamaan 
lintas budaya atas persepsi terhadap ponsel sebagai mode.

H5: Status/mode berpengaruh positif pada sikap terhadap penggunaan BlackBerry

\section{Sikap terhadap Penggunaan}

Sikap merupakan pendorong munculnya niat dan lebih jauh lagi, menginisiasi pembelian atau penggunaan. Dalam layanan mobile, sikap terhadap perilaku (penggunaan) mengacu pada perasaan evaluatif konsumen tentang melakukan perilaku (penggunaan), dan ada dukungan yang besar untuk efek positif dari sikap terhadap penggunaan layanan mobile dalam niat perilaku terhadap layanan mobile (Nysveen et al., 2005b).

Terdapat dukungan teoritis dan empiris dalam korelasi yang kuatan taraniat untuk terlibat dalam perilaku dan perilaku yang sebenarnya (Vijayasarathy, 2003). Choi et al. (2009) juga membuktikan bahwa sikap terhadap penggunaan TV mobile berpengaruh positif pada niat menggunakan TV mobile. Sikap terhadap penggunaan TV mobile juga terbukti memediasi pengaruh kelima faktor pendorong yang meliputi hiburan, interaksi sosial, akses permanen, pelengah waktu, dan status/mode pada niat menggunakan TV mobile. Nysveen et al. mengusulkan sebuah model terintegrasi yang menunjukkan adanya pengaruh sikap yang menjadi mediator dari hubungan pengaruh motivasional dan niat penggunaan layanan mobile.

H6: Sikap terhadap penggunaan BlackBerry berpengaruh positif pada niat untuk menggunakan BlackBerry.

\section{METODE PENELITIAN}

Penelitian ini menggunakan pendekatan kuantitatif dengan metode survei yang menggunakan data primer dari kuesioner. Itemitem kuesioner atas variabel hiburan, interaksi sosial,akses permanen, pelengah waktu, status/mode, sikap terhadap penggunaan, dan niat menggunakan dibuat berdasarkan penelitian sebelumnya oleh Leung dan Wei (2000) dan Choi et al. (2009) dengan beberapa penyesuaian. Pengukuran menggunakan skala Likert 5 poin. Kuesioner dibuat dengan Google Docs dan alamatnya (link) disebar melalui pesan personal (inbox) ke akun-akun jejaring sosial seperti Twitter dan Facebook atau email target responden yang sudah dicari tahu dan dicatat sebelumnya oleh peneliti.

Sampel yang digunakan adalah mahasiswa di Yogyakarta yang bukan pengguna BlackBerry.Hal ini berdasarkan alasan bahwa kalangan muda adalah konsumen kunci dalam pasar media mobile pada kebanyakan negara OECD di Eropa, Amerika, dan regional Asia Pasifik. Kalangan muda memiliki waktu lenggang yang banyak, bisa hidup tanpa anggaran, dan kebanyakan dari mereka belum memiliki kendaraan sendiri. Semakin pentingnya difusi mobile pada kalangan muda telah membuat subjek ini menjadi populer dalam industri analis dan akademisi. Terlebih lagi, gaya hidup dan pola konsumsi kalangan muda dapat menentukan kecenderungan konsumsi dari seluruh penduduk (Choi et al., 2009).

Metode pengambilan sampel yang digunakan adalah non-probability sampling dengan teknik purposive sampling yang menggunakan judgment sampling. Judgment sampling berkaitan dengan pemilihan subjek yang menempati posisi terbaik untuk menyediakan informasi yang dibutuhkan seperti yang telah disebutkan dan dengan berbagai pertimbangan dan pemilihan pengambilan sampel yang telah diuraikan di atas. Jumlah responden dalam penelitian ini sebanyak 160 responden.

Penelitian ini menerapkan pengujian pendahuluan (pre-test) untuk mengetahui kualitas item-item dalam kuesioner yang dapat diketahui melalui tingkat validitas dan reliabilitasnya. Pengujian ini dilakukan dengan menyebarkan kuesioner terlebih dahulu kepada 40 responden. Setelah kuesioner terkumpul, selanjutnya dilakukan pengolahan data dan pengujian reliabilitas serta validitasnya. Jika terbukti valid dan reliabel, maka kuesioner dapat dilanjutkan untuk digunakan dalam penelitian ini.

\section{HASIL ANALISIS}

\section{Karakteristik Responden}

Responden yang digunakan pada penelitian ini adalah mahasiswa yang merupakan pengguna telepon seluler selain BlackBerry. Jumlah responden yang digunakan pada penelitian ini berjumlah 160 responden. Namun, dari 160 buah kuesioner yang terkumpul dari seluruh responden tersebut, yang memenuhi syarat untuk diuji, yaitu yang sesuai dengan target sampel dan terisi dengan baik dan lengkap 
adalah 151 buah. Terdapat 9 kuesioner yang tidak memenuhi syarat karena diisi oleh pengguna BlackBerry atau terdapat item yang tidak terisi dengan baik.

Karakteristik responden dijabarkan melalui empat hal, yaitu jenis kelamin, usia, pengeluaran per bulan, dan merek telepon seluler yang digunakan. Detil penjelasan karakteristik responden dapat dilihat pada Tabel 1.

\section{Uji Validitas}

Dalam penelitian ini, uji validitas yang digunakan adalah convergent validity dengan menggunakan confirmatory factor analysis dengan software SPSS 19 for windows.Uji validitas yang dilakukan pada 151 responden menunjukkan bahwa nilai KMO adalah 0,897 dan angka ini berada di atas 0,5 yang merupakan syarat validitas untuk selanjutnya dapat dilakukan analisis faktor. Begitu juga dengan nilai Tes Bartlett dengan Chi-Square sebesar 3351,743 dan signifikan pada 0,000 sehingga analisis faktor dapat dilakukan. Hasil analisis faktor membuktikan seluruh item yang digunakan dalam penelitian ini terbukti valid dengan nilai faktor loading di atas 0,4 .

\section{Uji Reliabilitas}

Uji Relialibitas pada penelitian ini menggunakan uji statistik alpha Cronbach. Semua variabel dalam penelitian ini dinyatakan reliabel. Hal tersebut ditunjukkan oleh nilai alpha Cronbach yang dihasilkan oleh semua variabel penelitian menunjukkan lebih dari 0,7 .

\section{Uji Hipotesis}

Dalam penelitian ini metode analisis yang digunakan adalah analisis regresi linear. Ada dua model analisis regresi linier yang digunakan dalam penelitian ini, yaitu analisis regresi linier berganda dan analisis regresi linier sederhana. Analisis regresi linear berganda dilakukan karena di dalam model terdapat lebih dari satu variabel independen yang mempengaruhi variabel dependen. Kedua analisis regresi linier tersebut dilakukan dengan menggunakan SPSS.

Tabel 1: Karakteristik Responden

\begin{tabular}{lll}
\hline Jenis Kelamin & & \\
\hline Jenis Kelamin & Jumlah & Presentase \\
\hline Pria & 63 & $41,72 \%$ \\
Wania & 88 & $58,28 \%$ \\
Usia & & \\
Usia (tahun) & Jumlah & Presentase \\
Kurang dari 20 & 2 & $1,33 \%$ \\
20 & 11 & $7,28 \%$ \\
21 & 50 & $33,11 \%$ \\
22 & 53 & $35,10 \%$ \\
23 & 19 & $12,58 \%$ \\
24 & 12 & $7,95 \%$ \\
25 & 3 & $1,99 \%$ \\
Lebih dari 25 & 1 & $0,66 \%$ \\
Pengeluaran per bulan & & \\
Pengeluaran & Jumlah & Presentase \\
Kurang dari Rp 750.000 & 56 & $37,09 \%$ \\
Rp 750.000 - Rp 1.500.000 & 49 & $32,45 \%$ \\
Rp 1.500.001 - Rp 2.500.000 & 36 & $23,84 \%$ \\
Rp 2.500.001 - Rp 4.000.000 & 5 & $3,31 \%$ \\
Lebih dari Rp 4.000.000 & 5 & $3,31 \%$ \\
Merk telepon yang digunakan & & \\
Merek Telepon Selular & Jumlah & Presentase \\
Nokia & 78 & $51,66 \%$ \\
Sony Ericsson & 37 & $24,50 \%$ \\
iPhone & 13 & $8,61 \%$ \\
Samsung & 10 & $6,62 \%$ \\
LG & 7 & $4,64 \%$ \\
Merek lainnya & 6 & $3,97 \%$ \\
\hline
\end{tabular}


Tabel 2: Model Summary

\begin{tabular}{lllll}
\hline Model & $\mathrm{R}$ & R Square & $\begin{array}{l}\text { Adjusted } \mathrm{R} \\
\text { Square }\end{array}$ & $\begin{array}{l}\text { Std. Error of the } \\
\text { Estimate }\end{array}$ \\
\hline 1 & $.661^{\mathrm{a}}$ & .437 & .418 & .45255
\end{tabular}

a. Predictors: (Constant), SM, AP, H, PW, IS

Tabel 3: ANOVA $^{\mathrm{b}}$

\begin{tabular}{|c|c|c|c|c|c|c|}
\hline \multicolumn{2}{|l|}{ Model } & \multicolumn{2}{|c|}{ Sum of Squares df } & Mean Square & $\mathrm{F}$ & Sig. \\
\hline \multirow[t]{3}{*}{1} & Regression & 23.042 & 5 & 4.608 & 22.502 & $.000^{\mathrm{a}}$ \\
\hline & Residual & 29.696 & 145 & .205 & & \\
\hline & Total & 52.739 & 150 & & & \\
\hline
\end{tabular}

a. Predictors: (Constant), SM, AP, H, PW, IS

b. Dependent Variable: SP

Tabel 4: Coefficients ${ }^{\mathrm{a}}$

\begin{tabular}{|c|c|c|c|c|c|c|}
\hline \multirow[b]{2}{*}{ Model } & & \multicolumn{2}{|c|}{ Unstandardized Coefficients } & \multicolumn{2}{|l|}{$\begin{array}{l}\text { Standardized } \\
\text { Coefficients }\end{array}$} & \multirow[b]{2}{*}{ Sig. } \\
\hline & & $\mathrm{B}$ & Std. Error & Beta & $\mathrm{t}$ & \\
\hline 1 & (Constant) & 1.531 & .205 & & 7.458 & .000 \\
\hline & $\mathrm{H}$ & .121 & .055 & .177 & 2.199 & .029 \\
\hline & IS & .132 & .065 & .191 & 2.016 & .046 \\
\hline & AP & .140 & .066 & .192 & 2.108 & .037 \\
\hline & PW & .183 & .064 & .263 & 2.844 & .005 \\
\hline & SM & -.042 & .046 & -.066 & -.925 & .357 \\
\hline
\end{tabular}

a. Dependent Variable: SP

Berdasarkan Tabel 2, besarnya nilai adjusted $R^{2}$ adalah 0,418 , hal ini berarti $41,8 \%$ variasi dari variabel dependen yaitu sikap terhadap penggunaan (SP) dapat dijelaskan oleh variasi dari kelima variabel independen yaitu hiburan (H), interaksi sosial (IS), akses permanen (AP), pelengah waktu (PW), dan status/mode (SM). Sedangkan sisanya (100\% $41,8 \%)=58,2 \%$ dijelaskan oleh sebab-sebab yang lain diluar model.

Hasil Uji F-statistik pada Tabel 3 menunjukkan bahwa nilai $\mathrm{F}$ hitung sebesar 22,502 dengan probabilitas 0,000 . Probabilitas tersebut jauh lebih kecil dari 0,05 sehingga model regresi dapat digunakan untuk memprediksi sikap terhadap penggunaan (SP). Dengan kata lain, hiburan (H), interaksi sosial (IS), akses permanen (AP), pelengah waktu (PW), dan status/mode secara bersama-sama berpengaruh terhadap sikap terhadap penggunaan.

Untuk nilai $\mathrm{T}$ hitung, dari kelima variabel independen yang dimasukkan ke dalam model regresi, variabel status/mode (SM) menunjukkan hasil yang tidak signifikan. Hal ini dapat dilihat dari nilai $\mathrm{T}$ hitung SM sebesar -0,925 dengan probabilitas signifikansi sebesar 0,357 dimana nilai ini jauh di atas 0,05. Sedangkan H, IS, AP, dan PW signifikan karena nilai probabilitas signifikansinya di bawah 0,05. Dari sini dapat disimpulkan bahwa variabel sikap terhadap penggunaan dipengaruhi secara positif dan signifikan oleh variabel hiburan, interaksi sosial, akses permanen, dan pelengah waktu. Kemudian, dari empat variabel independen yang signifikan, ternyata variabel pelengah waktu mempunyai pengaruh yang paling kuat. Hal ini dapat dilihat dari nilai Beta PW $(0,263)$ yang paling tinggi dibanding variabel lainnya, yaitu hiburan $(0,177)$, interaksi sosial $(0,191)$, dan akses permanen $(0,192)$.

Hasil pengujian pada Tabel 4, dapat dirumuskan dengan formula sebagai berikut:

$$
\begin{array}{r}
S P=0,177 H+0,191 I S+0,192 A P+0,263 \\
(0,029) \quad(0,046) \quad(0,037) \quad(0,005)
\end{array}
$$

Formulasi tersebut menggunakan nilai standardized Beta sebagai koefisien regresi. Hal ini disebabkan karena nilai standardized Beta menunjukkan seberapa besar pengaruh variabel independen pada variabel dependen yang sudah bebas dari error. 
Tabel 5. Model Summary

\begin{tabular}{lllll}
\hline Model & $\mathrm{R}$ & $\mathrm{R}$ Square & $\begin{array}{l}\text { Adjusted } \mathrm{R} \\
\text { Square }\end{array}$ & $\begin{array}{l}\text { Std. Error of the } \\
\text { Estimate }\end{array}$ \\
\hline 1 & $.505^{\mathrm{a}}$ & .255 & .250 & .67355 \\
\hline
\end{tabular}

a. Predictors: (Constant), SP

Tabel 6. ANOVA ${ }^{\mathrm{b}}$

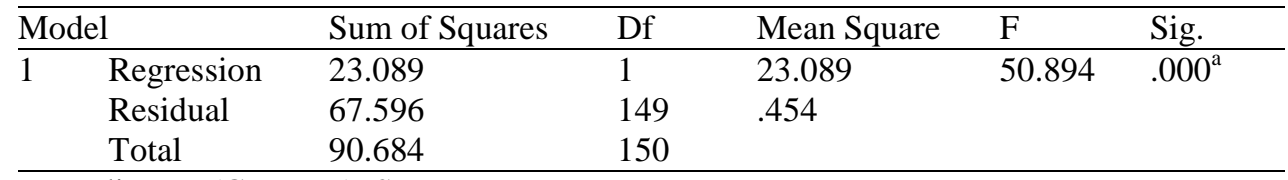

a. Predictors: (Constant), SP

b. Dependent Variable: NM

Tabel 7. Coefficients $\mathrm{s}^{\mathrm{a}}$

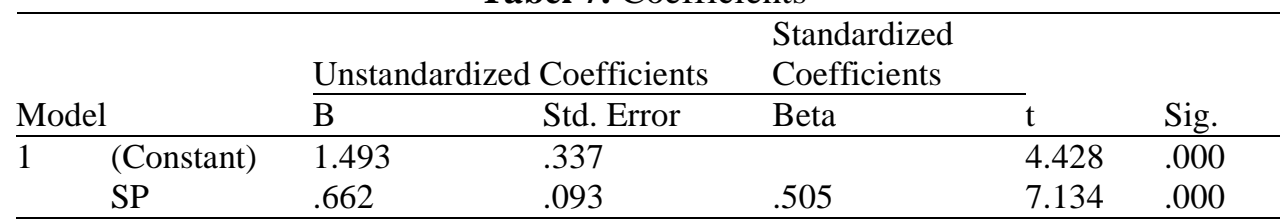

a. Dependent Variable: NM

Di samping analisis regresi linier berganda, dalam penelitian ini juga dilakukan analisis regresi linear sederhana untuk menguji kekuatan hubungan variabel independen yaitu sikap terhadap penggunaan terhadap variabel dependen yaitu niat menggunakan secara parsial.

Berdasarkan Tabel 5, besarnya nilai ${ }^{2}$ adalah 0,255 . Hal ini berarti $25,5 \%$ variasi dari variabel dependen yaitu niat menggunakan (NM) dapat dijelaskan oleh variasi dari variabel independen yaitu sikap terhadap penggunaan (SP). Sedangkan sisanya $(100 \%-25,5 \%)=$ $74,5 \%$ dijelaskan oleh sebab-sebab yang lain diluar model.

Hasil Uji F-statistik pada Tabel 6 menunjukkan bahwa nilai $\mathrm{F}$ hitung sebesar 50,894 dan memiliki probabilitas sebesar 0,000 . Probabilitas tersebut jauh lebih kecil dari 0,05 sehingga model regresi dapat digunakan untuk memprediksi niat menggunakan (NM).
Dengan kata lain, sikap terhadap penggunaan berpengaruh terhadap niat menggunakan.

Tabel 7 menunjukkan uji signifikansi parameter individual (Uji T). Pada tabel tersebut dapat diketahui bahwa variabel independen yaitu sikap terhadap penggunaan memiliki nilai $\mathrm{T}$ hitung sebesar 7,134 dengan probabilitas signifikansi di bawah 0,05. Dari hasil tersebut dapat dikatakan bahwa niat menggunakan dipengaruhi secara positif dan signifikan oleh sikap terhadap penggunaan.

Hasil pengujian pada Tabel 7, menunjukkan nilai Beta SP sebesar 0,505 yang kemudian dapat dirumuskan dengan formula sebagai berikut:

$$
N M=0,505 S P
$$

Untuk mempermudah melihat hasil pengujian hipotesis penelitian ini, maka dibuat Gambar 1.

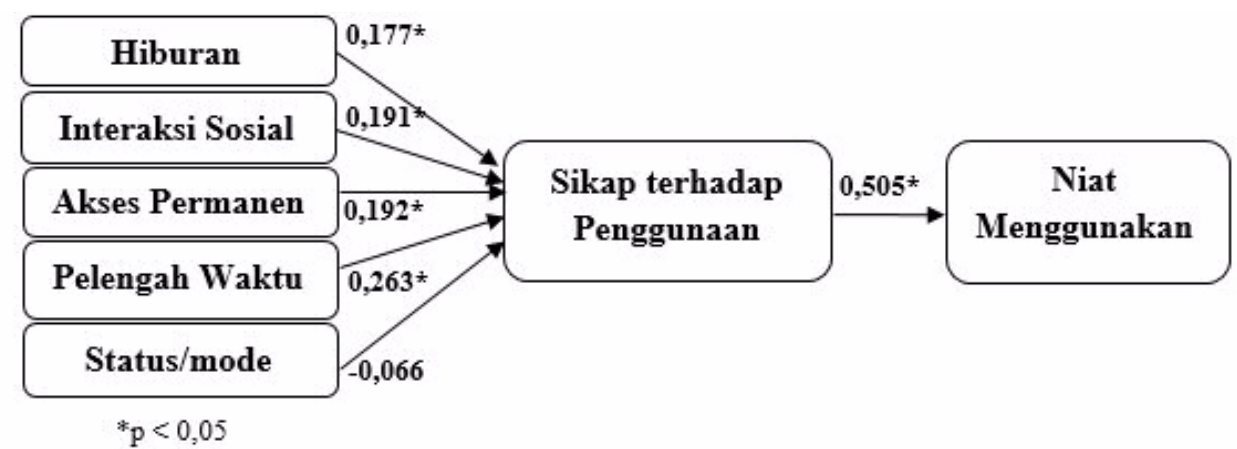

Gambar 1: Model Penelitian setelah Uji Hipotesis 


\section{Pengujian Hipotesis}

Tabel 8: Ringkasan Hasil Pengujian Hipotesis

\begin{tabular}{lllll}
\hline Hipotesis & Koefisien Beta & Nilai T-hitung & Signifikansi & Kesimpulan \\
\hline H1 & 0,177 & 2,199 & 0,029 & Didukung \\
H2 & 0,191 & 2,016 & 0,046 & Didukung \\
H3 & 0,192 & 2,108 & 0,037 & Didukung \\
H4 & 0,263 & 2,844 & 0,005 & Didukung \\
H5 & $-0,066$ & $-0,925$ & 0,357 & Tidak Didukung \\
H6 & 0,505 & 7,134 & 0,000 & Didukung \\
\hline
\end{tabular}

Tabel 8 memaparkan ringkasan dari pengujian hipotesis penelitian seperti yang telah dijelaskan dan diuraikan di atas.

Dalam pengujian $\mathrm{H} 1, \mathrm{H} 2, \mathrm{H} 3, \mathrm{H} 4$, dan $\mathrm{H} 5$, penelitian ini menginvestigasi hiburan, interaksi sosial, akses permanen, pelengah waktu, dan status/mode sikap terhadap penggunaan BlackBerry. Melalui model multiple regression, diperoleh hasil bahwa hiburan $(\beta=$ 0,177, T-hitung $=2,199, \mathrm{p}<0,05)$, interaksi sosial $(\beta=0,191$, T-hitung $=2,016, p<0,05)$, akses permanen $(\beta=0,192$, T-hitung $=2,108$, $\mathrm{p}<0,05)$ dan pelengah waktu $(\beta=0,263 \mathrm{~T}$ hitung $=2,844, \mathrm{p}<0,05)$ memiliki pengaruh yang signifikan dan positif pada sikap terhadap penggunaan BlackBerry. Sedangkan status/mode $(\beta=-0,066$, T-hitung $=-0,925, p>0,05)$ tidak memiliki pengaruh yang signifikan pada sikap terhadap penggunaan BlackBerry. Meskipun ada variabel yang tidak memberikan pengaruh signifikan, model penelitian ini tetap menjelaskan variasi variabel penelitian pada variasi variabel kegunaan informasi secara signifikan yang ditunjukkan oleh nilai $\mathrm{R}^{2}$ sebesar $43,7 \%$, $\mathrm{F}$-value $=22,502, \mathrm{p}<0,05$.

Selanjutnya, dalam pengujian H6, penelitian ini menginvestigasi sikap terhadap penggunaan BlackBerry pada niat menggunakan BlackBerry. Melalui model regresi sederhana, diperoleh hasil sikap terhadap penggunaan BlackBerry $(\beta=0,505$, nilai $\mathrm{T}$-hitung $=$ $7,134, p<0,05)$ memiliki pengaruh yang positif dan signifikan pada niat menggunakan BlackBerry. Model penelitian ini menjelaskan variasi variabel kegunaan informasi pada variasi variabel adopsi informasi secara signifikan yang ditunjukkan oleh nilai $\mathrm{R}^{2}$ sebesar $25,5 \%$, Fvalue $=50,894, p<0,05$.

\section{PEMBAHASAN}

Penelitian ini menghasilkan hasilpenelitian yang sedikit berbeda dengan penelitian- penelitian sebelumnya. Dalam penelitian ini, hiburan, interaksi sosial, akses permanen, dan pelengah waktu terbukti berpengaruh secara signifikan dan positif pada sikap terhadap penggunaan BlackBerry. Sedangkan status/mode tidak berpengaruh signifikan pada sikap terhadap penggunaan BlackBerry. Pelengah waktu yang dalam penelitian Choi et al.(2009) terbukti tidak berpengaruh posistif pada sikap terhadap penggunaan, dalam penelitian ini terbukti sebaliknya. Pelengah waktu terbukti berpengaruh positif pada sikap terhadap penggunaan BlackBerry. Hasil ini sejalan dengan penelitian yang dilakukan oleh Leung dan Wei (2008) dengan objek telepon seluler dan Papacharissi dan Rubin (2000) dengan objek internet.

Status/mode ditemukan tidak berpengaruh signifikan pada sikap terhadap penggunaan BlackBerry. Hal ini berarti bahwa status/mode tidak dapat mendorong terbentuknya persepsi seseorang pada penggunaan BlackBerry sebagai sesuatu yang menunjukkan mode, gaya, dan idenditasnya. Pada penelitian sebelumnya, Choi et al. (2009) yang menggunakan gender sebagai moderasi sebenarnya membuktikan bahwa pengaruh positif status/mode pada sikap terhadap penggunaan hanya muncul pada kaum pria. Pada wanita, status/mode terbukti juga tidak berpengaruh positif pada sikap terhadap penggunaan. Selain penelitian Choi et al. (2009) tersebut, Nysveen et al. (2005b) yang meneliti sikap dan niat menggunakan layanan mobile juga membuktikan bahwa keekspresifan (yang dapat dibandingkan dengan status/mode) berpengaruh positif pada sikap terhadap penggunaan dan pengaruh tersebut hanya muncul pada kaum pria saja.

Melihat statistik demografi responden penelitian ini, responden wanita memang lebih banyak dibandingkan dengan pria dimana presentase wanita sebesar $58,28 \%$ sedangkan pria $41,72 \%$. Dominasi wanita dalam respon- 
den penelitian ini mungkin menyebabkan status/mode tidak dapat mendorong terbentuknya persepsi seseorang pada penggunaan BlackBerry sebagai sesuatu yang menunjukkan mode, gaya, dan idenditasnya. Hal ini sejalan dengan hasil penelitan Nysveen et al. (2005b) dan Choi et al. (2009) yang sudah dijelaskan sebelumnya.

Faktor-faktor yang memungkinkan terjadinya perbedaan yang terjadi dalam penelitian Nysveen et al. (2005b), Choi et al. (2009) dan mungkin juga dalam penelitian ini adalah adanya perbedaan gaya dan pola komunikasi antara pria dan wanita. Pola komunikasi pria cenderung berdasarkan pada gagasan hirarki sosial, sedangkan wanita cenderung berorientasi pada jaringan. Bagi wanita, komunikasi merupakan cara untuk membentuk hubungan dan relasi negosiasi sehingga dalam konteks penggunaan BlackBerry yang merupakan alat komunikasi, wanita lebih berorientasi pada interaksi sosial dari pada status/mode. Sedangkan pria, komunikasi berarti menunjukkan kemandirian dan negosiasi serta menjaga status dalam fungsi hirarki sosial. Hal tersebut dilakukan dengan menunjukkan pengetahuan dan keterampilan serta dengan menjadi pusat perhatian melalui penampilan verbal seperti bercerita, bergurau, dan memberikan informasi. Sejak kecil, pria belajar untuk menggunakan kemampuan verbal sebagai cara untuk menarik dan menjaga perhatian sehingga pria lebih nyaman untuk berbicara dalam kelompok besar yang mereka kenal baik dan bukan pada pembicaraan privat (Tannen, 1990).

Gefen dan Straub (1997) juga menyatakan bahwa wanita lebih fokus pada menciptakan keintiman, dukungan dan konsesus sedangkan pria lebih fokus pada penegasan kemandirian, mencari perhatian dan mencapai kedudukan sosial. Dalam penelitian ini, pria kurang menyukai ide penggunaan BlackBerry berdasarkan faktor status/mode mungkin dikarenakan BlackBerry merupakan alat komunikasi yang umumnya menghubungkan satu orang dengan orang lainnya, dengan kata lain BlackBerry lebih cenderung mengakomodasi pembicaraan privat, bukan pembicaraan dalam suatu kelompok besar. Walaupun dalam fitur BlackBerry Messanger (BBM) terdapat grupgrup tertentu, namun komunikasi tersebut bukan komunikasi verbal, melainkan tertulis. Pembicaraan privat dan pembicaraan tertulis dalam kelompok besar, bagi pria belum bisa membantu mereka dalam menunjukkan kemandirian serta menarik perhatian orang banyak.

Alasan lain yang menyebabkan status/mode tidak berpengaruh positif pada sikap terhadap penggunaan BlackBerry adalah cepatnya pertumbuhan inovasi teknologi yang menyebabkan suatu penciptaan teknologi baru cepat dinilai usang. Banyaknya pemain dalam teknologi telepon seluler di Indonesia menyebabkan makin ramainya persaingan antar perusahaan sehingga setiap perusahaan akan selalu berusaha menciptakan inovasi-inovasi baru. Inovasi baru tersebut membuat inovasi yang telah dulu ada menjadi usang. Awalnya, sebuah inovasi baru akan dianggap sebagai sesuatu yang bernilai tinggi. Namun selang sebentar muncul inovasi baru lainnya yang menurunkan nilai inovasi yang lama (Keegan dan Green, 2005, h. 566).

Nysveen et al. (2005a) dalam penelitiannya yang membandingkan 4 layanan mobile, hasil menunjukkan bahwa keekspresifan (status/mode) hanya berpengaruh positif pada sikap terhadap penggunaan layanan pembayaran mobile (mobile payment services). Sedangkan untuk 3 layanan lain, yaitu text messaging, layanan permainan, layanan kontak, tidak muncul pengaruh tersebut. Terkait dengan BlackBerry yang dapat memfasilitasi layanan mobile dan responden yang merupakan mahasiswa, layanan pembayanan mobile dimungkinkan bukan menjadi salah satu layanan mobile yang mereka butuhkan atau inginkan. Diketahui bahwa kebanyakan mahasiswa masih belum memiliki pendapatan sendiri. Pembayaran dana pendidikan masih ditanggung oleh orang tua. Layanan perbankan yang kebanyakan mereka gunakan adalah kartu ATM. Transaksi yang mereka lakukan juga masih terbatas, sehingga layanan pembayaran mobile belum mereka inginkan terdapat dalam telepon seluler mereka.

Pengujian hipotesis pertama hingga ketiga menunjukkan bahwa hiburan, interaksi sosial, dan akses permanen, terbukti berpengaruh pada sikap terhadap penggunaan BlackBerry. Hasil ini sejalan dengan penelitian terdahulu yang dilakukan oleh Choi et al. (2009), Leung dan Wei (2008), dan Nysveen et al. (2005a,b). Hiburan terbukti menjadi faktor yang membentuk persepsi positif seseorang 
pada penggunaan BlackBerry yang dapat menjadi suatu kegiatan menghibur dan menyenangkan. Interaksi sosial juga terbukti menjadi faktor yang membentuk persepsi positif seseorang pada penggunaan BlackBerry yang dapat memungkinkan interaksi/komunikasi sosial. Selain itu, akses permanen juga terbukti menjadi faktor yang membentuk persepsi positif seseorang pada penggunaan BlackBerry yang mengakomodasi pengguna untuk mendapatkan akses langsung tanpa harus memikirkan waktu dan tempat.

Selain kelima hipotesis yang telah dijelaskan sebelumnya, sikap terhadap penggunaan BlackBerry juga terbukti berpengaruh positif pada niat menggunakan BlackBerry. Sikap tersebut mengacu pada perasaan evaluatif seseorang tentang ide penggunaan BlackBerry. Dengan kata lain, sikap terhadap penggunaan BlackBerry mendorong munculnya niat untuk menggunakanan dan lebih jauh lagi dapat menginisiasi pembelian. Hasil penelitian ini juga sejalan dengan penelitian yang telah dilakukan Choi et al. (2009), dan Nysveen et al. $(2005 a, b)$. Terdapat dukungan yang besar bagi efek positif dari sikap terhadap penggunaan BlackBerry pada niat menggunakan BlackBerry.

\section{Keterbatasan dan Saran bagi Penelitian Selanjutnya}

Responden yang digunakan pada penelitian ini hanya mahasiswa di Yogyakarta, sehingga menyebabkan hasil dari penelitian ini tidak dapat digeneralisasikan pada pengguna telepon seluler seluruhnya. Boleh jadi, penelitian pada responden dengan karakteristik demografis yang beragam akan menghasilkan hasil penelitian yang berbeda.

Pengambilan data melalui kuesioner yang sebagian besar diberikan kepada mahasiswa melalui online memungkinkan responden penerima kuesioner dapat menyebarkan kusioner kepada responden lain yang tidak sesuai dengan target sampel sehinggaterjadi pengisian kuesioner dengan data yang bias. Namun hal ini sudah diantisipasi dengan narasi dan pertanyaan dalam kuesioner yang menyebutkan siapa target responden yang sebenarnya serta screening isian pada data responden.

Item-item pertanyaan dalam kuesioner mengalami pengalihan bahasa, yang memung- kinkan responden memiliki persepsi berbeda dengan persepsi peneliti. Sehingga, dimungkinkan terdapat kesalahan interpretasi oleh para responden dalam menjawab item-item pertanyaan.

\section{Saran Bagi Penelitian Selanjutnya}

Model dalam penelitian ini dapat digunakan untuk mengukur sikap terhadap penggunaan dan niat menggunakan pada objek lain yang berkaitan dengan teknologi atau sistem informasi dan diharapkan penelitian selanjutnya dapat dilakukan dengan mengembangkan model ini dengan menambahkan variabel lain yang belum digunakan dalam penelitian ini seperti kegunaan dan kemudahaan penggunaan yang diusulkan oleh Nysveen et al. (2005a,b).

Penelitian selanjutnya dapat menggunakan sampel yang lebih besar dari berbagai kalangan, tidak hanya pada kalangan mahasiswa sehingga akan menghasilkan kondisi yang sebenarnya. Pada penelitian selanjutnya diharapkan butir-butir pertanyaan dapat diperbaiki dan diperjelas agar responden dapat lebih mudah mencerna pertanyaan dalam kuesioner.

\section{DAFTAR PUSTAKA}

Ajzen, Icek 1991.The Theory of Planned Behavior. Organizational Behavior and Human Decision Processes 50, 179-211

Akturan, U., \& Tezcan, N. 2012. Mobile banking adoption of the youth market: Perceptions and intentions. Marketing Intelligence \& Planning, 30(4), 444459.

APJII dan Puskakom UI. 2015, Profil Pengguna Internet Indonesia 2014. Jakarta: APJII.

Aoki, K. and Downes, E. J. 2002, An Analysis of Young People's Use of and Attitudes Toward Cell Phones, Telematics and Informatics, Vol. 20, pp. 349-364.

Campbell, S. W. (2007), A Cross-Cultural Comparison of Perceptions and Uses of Mobile Telephony, International Journal of Communication, Vol. 1, pp. 738-757. 
Choi, Y. K.; Kim, J.; and McMillan, S. J. 2009, Motivators for the Intention to Use Mobile TV: A Comparison of South Korean Males and Females, International Journal of Advertising, Vol. 28, pp. 147-167.

Christiansen, E. M. and Brinkerhoff-Jacobs, J. (1995), Gaming and Entertainment: An Imperfect Union?, Cornell Hotel and Restaurant Administration Quarterly, Vol. 36, No. 2, pp. 79.

Davis, F.D. (1989), Perceived Usefulness, Perceived Ease of Use, and User Acceptance of Information Technology, MIS Quarterly, Vol. 13, No.3, pp. 319-340.

Davis, F. D., Bagozzi, R. P., \& Warshaw, P. R. 1989. User acceptance of computer technology: a comparison of two theoretical models. Management science, 35(8), 982-1003.

Davis, F.D. 1993, User Acceptance of Information Technology: System Characteristics, User Perceptions and Behavioral Impacts, International Journal Management Machine Studies, Vol. 38, pp. 475-487.

Dharmmesta, B. S. 1992, Riset tentang Minat dan Perilaku Konsumen: Sebuah Catatan dan Tantangan bagi Peneliti yang Mengacu pada Theory of Reasoned Action, JEBI, No. 1, Tahun VII 1992, pp. 39-53.

Fishbein, $M$ and Ajzen I. 1975. Beliefs, Attitude, Intention and Behavior. New Yok: Addison-Wesley Publishing Company, INC.

Gefen, D. and Straub, D. W. 1997, Gender Differences in the Perception and Use of E-mail: An Extention to the Technology Acceptance Model, MIS Quarterly, Vol 21, No 4, pp. 389-400.

Hung, S. Y.; Cheng-Yuan, K.; and Chang, C. M. 2003, Critical Factors of WAP Services Adoption: An Empirical Study, Electronic Commerce Research and Applicantions, Vol.2. pp. 42 -60.
Jin, C. H. and Villegas, J. 2008, Mobile Phone User's Behaviors: the Motivation Factors of the Mobile Phone User, International Journal of Mobile Marketing, Vol. 3, No. 2, pp. 4-14.

Katz, E. and Blumler, J. G. 1974, The Uses of Mass Communications: Current Perspectives on Gratifications Research, Beverly Hills, CA: Sage.

Keegan, Warren J. and Green, Marc C. (2005), Global Marketing, $4^{\text {th }}$ ed.Upper Saddler River, New Jersey: Pearson Prentice Hall.

Kotler, P. and Armstrong, G. 2008, Principles of Marketing, $12^{\text {th }}$ ed. Upper Saddler River, New Jersey: Pearson Prentice Hall.

Koufaris, Marios. 2002, Applying the Technology Acceptance Model and Flow Theory to Online Consumer Behavior. Information System Research, Vol 13, No. 2, pp. 205 223.

Leung, L. and Wei, R. 2000, More Than Just Talk on the Move: Uses and Gratifications of the Cellular Phone, Jornalism and Mass Communication Quartely, Vol. 77, No. 2, pp. 308-320.

Mix (2009), Bisakah Nokia Membendung BB?. Jakarta: Sembada Swakarya.

Nasri, W., \& Charfeddine, L. 2012. Factors affecting the adoption of Internet banking in Tunisia: An integration theory of acceptance model and theory of planned behavior. The Journal of High Technology Management Research, 23(1), 1-14.

Nysveen, H.; Pedersen, P. E.; dan Thorbjørnsen, H. 2005a, Explaining Intention to Use Mobile Chat Services: Moderating Effects of Gender, Journal of Consumer Marketing, Vol 22, No 5, pp. 247-256

Nysveen, H.; Pedersen, P.; dan Thorbjornsen, H. 2005b, Intentions to Use Mobile Services: Antecedents and CrossService Comparisons,Journal of 
Academy of Marketing Science, Vol. 33, No. 3, pp. 330-346.

O'Keefe, G. J. and Sulanowki, B. K. 1995, More Than Just Talk: Uses, Gratifications and the Telephone, Journalism and Mass Communication Quartely, Vol. 72, No. 4, pp. 922-933.

Papcharissi, Z. and Rubin, A. M. 2000 Predictors of Internet Use, Journal of Broadcasting and Electronic Media, Vol. 44, No. 2, pp. 175-196.

Puro, J. 2002, Finland: a Mobile Culture, In Katz, J. and Aakhus, M. (Eds), Perpetual Contact: Mobile Communication, Private Talk, Public Performance. New York: Cambridge University Pree, pp. 19-29.

Rubin, A. M. 1984, Ritualized Instrumental Television Viewing, Journal of Communication, Vol. 34, No. 3, pp. 67-77.

Ruggiero, T. E. 2000, Uses and Grativication Theory in the 21st Century, Mass Communication and Society, Vol. 3, No. 1, pp. 3-37.

Schierz, P. G., Schilke, O., \& Wirtz, B. W. 2010. Understanding consumer acceptance of mobile payment services: An empirical analysis. Electronic com- merce research and applications, 9(3), 209-216.

Taylor, A. S. and Harper, R. 2001. The Gift of The Gab?: A Design oriented Sociology of Young People's Use of 'MobilZe!', Journal of Computer Supported Cooperative Work (JCSCW), Vol. 12, No. 3, pp. 267-296.

Teo, T. S. H.; Lim, V. K. G.: and Lai, R. Y. C. 1999, Intrinsic and Extrinsic Motivation in Internet Usage, The Internet Journal of Management Science, Vol. 27, pp. 25-37.

Venkatesh, V., Morris, M. G., Davis, G. B., \& Davis, F. D. 2003. User acceptance of information technology: Toward a unified view. MIS quarterly, 425-478.

Vijayasarathy, Leo R. 2003. Predicting Consumer Intentions to Use On-Line Shopping: The Case for an Augmented Technology Acceptance Model,Journal of Information dan Management, Vol.41,pp. 747-762.

Wang, C.C.; Hsu, Y.H.; and Fang, W. 2005, Acceptance to Technology with Network Externalities: An Empirical Study of Internet Instant Messaging Services, Journal of Information Technology Theory and Application, Vol. 6. No. 4. pp. 15-28 